\title{
The Network-Firm as a Single Real Entity: Beyond the Aggregate of Distinct Legal Entities
}

\author{
Author: Virgile Chassagnon \\ Affiliation: University of Lyon /LEFI (Laboratoire d'Economie de la Firme et \\ des Institutions), Virgile.chassagnon@ish-lyon.cnrs.fr, Tel : (33) 04.72.72.64.58, \\ Fax : (33) 04.72.72.65.55.
}

\begin{abstract}
.
This paper intends to depart from a critique of the nexus of contracts theory of the firm endowed with its moral personification to propose some theoretical foundations of the firm as a real entity. Some old legal views of the corporation are mobilized to complete the conceptual vacuity of economic theories. This provides crucial insights for modern complex organizations such as the networkfirm. The integrating and unifying role of intra-network power relationships is then emphasized and some law and economics of the network-firm are ultimately proposed to clarify the argument that the network-firm - as the firm stricto sensu - is a singular real entity composed from distinct legal entities.
\end{abstract}

Keywords.

Law and economics, contract theory of the firm, network-firm, legal fiction, real entity

\section{INTRODUCTION}

The theory of the firm field is fundamentally concerned with defining the nature of the firm. In essence, the firm is traditionally recognized as a legal person called societate that is distinct from the actual persons who compose it. The firm is the creation of law that provides capacity to enter into legal relations, and the entity upon which the law confers such personality is a moral person (Foley, 1929). The dominant economic theories of the firm do not lead to something else, denying the fundamental differences between contract and organization and reformulating the firm as a 'nexus of contracts' (Jensen and Meckling, 1976) or as a 'collection of non-human assets' (Moore, 1992). Hence, the firm is nothing more than a fictitious or an aggregative entity that serves as a nexus for a set of contractual 
relationships among individuals. But is the firm simply a nexus of contracts? If not, what really is the nature of the firm?

According to the nexus of contracts view, the firm does not exist as such. The firm is a simple abstraction which would have no existence without a name. But the firm is real and is neither a fiction nor an aggregate. The legal theory of the firm has become a topic of strong intellectual debate between legal fiction and real entity approaches of the corporation. Reducing the firm to a nexus of contracts is not suitable to disclose its real nature. The main step for theorizing the firm is to recognize it as a real entity, i.e., as a cohesive and durable whole of integrated human and non-human constituents that is other than a sum of its parts and members. The real single entity 'firm' is perpetuated by an institutional and organizational glue that holds the complex whole together. This glue unifies some particular individual entities into a singular collective entity. The first research aim of the paper is therefore to propose some theoretical foundations of the firm ${ }^{1}$ as a real entity.

The central focus of this article is the firm taken in an economic, and so in a large, sense. That's why it is interesting to extend the proposition that the firm is a real entity to a modern form of vertical economic organization: the networkfirm. This latter links some legally autonomous firms into a single productive system through a hub-firm that has the de facto power to control the whole without recourse to equity ownership. The network-firm is not a firm taken in a legal sense. The determination of the boundaries of that entity is difficult because the economic integration of the network-firm transcends the legal boundaries of the firm (Rajan and Zingales, 2000). The choice of the relevant unit of analysis is hence an important issue to raise. Is the network-firm just a set of distinct legal entities or a single real entity?

The integration of the whole network cannot be reduced to contract and ownership but must be extended to power arising wherever the economic dependence of one party upon the other is effectively significant. Power is not exclusively provided by ownership but as well by control and access to critical resources. The more critical resources, the stronger the whole power. The emergence of such complex organizations implies that it is crucial to develop an understanding of network logic that relies on multiple constructs which would come from different origins as economics, legal theory and other social sectors involved (Teubner, 2002). Beyond the range of employment protection laws and beyond politico-legal liability, the theorization of the network-firm as a single real entity highlights some issues in law. This shows that the legal entity status provided by the law is very important and cannot be neglected (Hodgson, 2002) but is clearly not sufficient to apprehend the nature of the firm. The second

${ }^{1}$ A theory of the firm has to address the issues of the nature, the boundaries and the internal organisation - cooperation - of the firm. 
research aim of the paper is then to reveal that the definition of the firm as a real entity allows us to shed light on the nature of modern economic organizations.

The rest of the article is organized in five sections. Section 2 explains the theoretical way which leads from a theory of the firm as a legal fiction to a theory of the firm as a real entity. Section 3 proposes an economic characterization of the network-firm as a complex relational entity. Section 4 argues that this form of productive organization is more than a matter of contracts because of the importance of intra-network power relationships. Section 5 clarifies the fact that even though corporate law distinguishes several entities two or more separate legal entities forming a network-firm act as a single real entity. Section 6 concludes.

\section{ON THE SEMINAL QUESTION OF THE NATURE OF THE FIRM}

In this section, the question of the nature of the firm is approached from the point of view of dominant economic theories. Accordingly, this section sheds light on the reductionist position of theories advocating the personification of the firm by the metaphor of law. The firm is neither a legal fiction nor an aggregate but a real entity. Some theoretical bases are proposed for an ontological recognition of the firm as a real entity.

\subsection{The firm as a legal fiction}

According to mainstream theories, the nature of the firm is based on the organization of a bundle of some different contractual arrangements. The firm is a nexus of contracts. Contract is the central modular mechanism able to play both a coordinating and incentive provision role within and between firms. Such a contractual analysis implies some sense of continuity between the firm and the market. Contractual relations are the essence of firms and human beings are parties to this nexus of contracts. Individuals exist only as regards with contracts. There are no strict ontological differences between contract and organization since organizations should be seen as contractual arrangements through which transactions pass smoothly. The firm differs from market not in nature but in degree because the contract is the basis of all governance structures. Alchian and Demsetz (1972:785) consider that the classical firm is a 'particular contractual structure' 2 that possesses the properties of an efficient market, i.e, a team whose value exceeds the sum of the market values each could get separately and where contracts aim to restrain and control the actions of individuals.

2 Alchian and Demsetz (1972:794) argue that 'the terms of the contracts form the basis of the entity called the firm'. They add that technological inseparability needs joint production, which is sensed to define a nexus of particular contracts. This latter is a firm. 
The modern theory of property rights, which defines the firm as a collection of non-human assets, revolves about this theory of the firm as a nexus of contracts insisting that firms arise where market contractual relationships fail. According to the nexus of contracts view, it is not useful to determine what a firm is and what it is not (Cheung, 1983). On the contrary, the collection of assets view of the firm states that the understandings of the nature and boundaries of the firm are intimately correlated and matter ${ }^{3}$. The modern property rights theory has tried to explain firm boundaries in terms of the optimal allocation of assets ownership. The assets which are held by the firm form this one and not the others. The holder of residual rights of control ${ }^{4}$ over non-human assets in a coalition has power over human capital owners who need non-human assets in order to be productive, so that 'control over a physical asset in this line can lead indirectly to control over human assets' (Hart and Moore, 1990:1121). In a world of incomplete contracts subject to renegotiation later on, the firm as an institution takes on importance and the extension of the size of the firm is a solution to allocate efficiently residual rights of control (Grossman and Hart, 1986). The firm becomes a single 'owner' that has residual rights of control on these assets. As for the non-human assets, they constitute the glue that keeps the firm together. Without this glue, the firm is 'just a phantom' (Hart, 1995:57). Ultimately, even in transaction cost economics, where the firm is a governance structure coordinated by a hierarchical authority coming from a 'private ordering' (Williamson, 2002), the basic unit of analysis is transaction, i.e., the type of contracts.

Arguably, these economic theories have in common to tie the nature of the firm to a contractual essence. The firm is just 'an aggregate formed by private contracting among its human parts' (Phillips, 1994:1065). The legal personification of the firm promotes its representation. But from when is a nexus of contracts a firm (Demsetz, 1988)? The answer is never both because otherwise the firm would be just a sum of contracts and individuals who own resources and nothing more and because 'the reasoning cannot escape circularity since one cannot identify a nexus of contracts independently of a given firm' (Gindis, 2007:270).

The nexus of explicit contracts view, which is as influent in economic theory as in corporate law theory, proposes an incomplete theoretical treatment of the nature of the firm. In this view, 'we do not exactly know what a firm is' because the firm is 'a shorthand description of a way to organize activities under contractual arrangements' (Cheung, 1983:3). The nexus of contracts theory does not recognize the firm distinctly from its parts but determines its nature as regards

${ }^{3}$ Even if it is obviously impossible 'to draw a hard and fast line which determines whether there is a firm or not' (Coase, 1937:392).

4 The residual right of control of an asset is 'the right to control all aspects of the asset that have not been explicitly given away by contract' (Grossman and Hart, 1986:695). 
with the relations between its aggregated parts. Bratton (1989:1498) concludes that 'some transactions involve the fictive firm entity as a party, but only as a matter of convenience'. The firm is a legal person that is nothing more than an artificial entity that exists only by the way of metaphor (fiction) of law. Jensen and Meckling (1976:312) insist on the fact that 'most organizations are simply legal fictions which serve as a nexus of contracting relationships among individuals'.

By a legal fiction it is meant that an economic organization must be treated as a single individual. Since the firm is a nexus of contracts, those contracts must have parties. But a single individual aggregates these parties. The firm is a person, i.e., a 'right-and-duty-bearing unit'. To confer legal rights or to impose legal duties is to confer legal personality and 'the rights and duties of the fictitious person correspond closely to those of an actual person' (Williston, 1888:107). The corporation can own assets, negotiate and sign contracts and sue or be sued. But if corporate personality is a fiction, it is fallacious to argue that the entity, which is personified, is fictitious (Machen, 1911). From then on, an epistemological question arises: are firms 'natural outcomes of human social life or derivative and sterile creations of positive laws' (Mark, 1987:1468)?

Treating the firm as a fiction is similar to say that the firm does not exist. Since the firm does not exist then it could not have responsibilities. Yet the corporation has rights and liabilities in tort. Furthermore, the firm as an institution has responsibilities which go beyond the residual claims of owners of capital (Collins, 1993). But the firm does not have human wants, motivations or intentions. The firm does not really behave but individuals do. For all that, the firm is not a mere sum of individuals having duties and rights defined by legal relationships of contract and property. If a corporation is the sum of its human components, 'how can it decide to act unless every member agrees to the action in question' (Phillips, 1994:1083)?

The law cannot explain how individuals bind themselves in a firm. Firms are singular entities that develop collectively a 'cognitive capacity' and an ability to 'act' in certain ways. However, all reference to psychic organisms is 'either gratuitous or highly misleading' (Dewey, 1926:673). Cohen (1935:811) reminds that 'nobody has ever seen a corporation' and warns against 'transcendental nonsense'. The corporate person is a representation of social realities which the law recognizes but does not create. In other words, 'the necessity for persons to compose the corporation results from the nature of things rather than from any rule of law' (Williston, 1888:114). The firm is neither a fictitious entity nor a living organism, contrary to the natural entity view of Maitland (1905). McKelvey (1997:352) extends this argument by defining firms as quasi-natural entities that 'result from both individual human intentionality and natural causes independent of individual's intended behavior'. Groups, such as firms, have a 
social identity of their own that differs from the identities of individuals who create them.

According to aggregate theories, shareholders circumscribe the legal entity called 'firm'. Shareholders are the aggregate's key figures. They constitute only one person in law so that they are the firm (Ireland, 1999) ${ }^{5}$. But shareholders do not own the firm as such. No one owns the firm and the 'corporation's being person implies that it cannot be considered as an object of property rights' (Gindis, 2007:272). In other words, 'corporate assets belong not to shareholders but to the corporation itself' (Blair and Stout, 1999:250-251). This gives food for thought that the firm is not a nexus of owners. Consequently, the firm cannot be treated as a set of individuals aggregated into a homogenous group of interests called 'the owner'. The firm must be recognized as 'an end in itself', which needs a model of corporate behaviour which gives it existence independent from shareholders (Kay and Silberston, 1995).

In a firm, some different individualities act in a unified way. So the firm is 'an organised body of men acting as a unit, and with a will that has become unified though the singleness of their purpose' (Laski, 1916:424). Brown (1905) writes precisely that whenever men act in common they inevitably tend to develop a spirit which is something different from themselves taken singly or in sum. Individuals bind themselves to act for some common purpose. They form a real entity which, by no fiction of law, differs from individuals of whom it is constituted (Dicey, 1904).

\subsection{The firm as a real entity}

The reductionist theoretical treatment of the firm as a nexus of contracts falls under a ubiquitous methodological individualism. But, if it seems wrong to reduce the dynamics of social processes to individual's actions, it is equally wrong to see collectivities such as the legal person as mere shorthand expressions for the complex aggregates of individual actions (Teubner, 1988). While the firm exists independently of its individual members, it does not 'act' in a way that is apart from them. The parts are as real as the whole. Inside the firm, 'neither the individuals nor the relation they bear to one another is fictitious' (Raymond, 1906:362). The real entity paradigm portrays corporations as distinct from their individual members, though, like them, they had real existence (Tsuk, 2003).

The split between the real entity and the fictitious entity goes hand in hand with the long running debate between so-called holists and methodological individualists. Nevertheless, there is no need here to discuss these methodological

${ }^{5}$ He explains that 'by facilitating recognition of the corporation not as an owner, nor as an object capable of being owned, but as a network of social and productive relationships, it would enable us to begin the process of reconceptualising the corporation and corporate property' (ibid.:56). 
concerns. Although the analysis of the firm implies shedding light on some holistic dimensions, any form of determinism must be excluded. To include why the firm is real, the postulate of emergence needs to be used. This one implies that properties of the whole cannot be reduced to properties of its constituents. Humphreys (1997:342) interestingly explains that emergent properties are 'qualitatively different from the properties from which they emerge' because they are properties of 'the entire system rather than local properties of its constituents'. The firm as a whole interacting system exhibits emergent properties that are both novel and largely unexpected (Holland, 1998). The firm is a real emergent entity.

Analyzing theoretically the firm as a real entity implies departing from the nexus of contracts theory which cannot explain that firms have social responsibilities to non-shareholders as employees or suppliers. Defining the firm from the real entity view comes to assert that the firm is something different than the sum of its parts. The firm is a social reality with an existence independent of, and constituting something more than, its changing parts (Blumberg, 1990). As the firm is an organization devoted to production, the firm can no longer be fictitious. Indeed, what does it mean for a mere nexus to be competitive? Each firm is an autonomous entity that competes with other singular entities. Firms are not all the same ones. Heterogeneity is an existential property of firms.

The term of 'real entity', exempt of all forms of living mankind, is very suitable to define firm's nature. Treating the firm as a real entity implies that the firm exists intrinsically and objectively. The firm is a complex system ${ }^{6}$ of human members and non-human parts which are interrelated and held together by some unexpected integrating forces. These forces which result from the exhibition of collective properties and emergent features can be seen as a 'glue'. The glue expresses the idea of a durable vector of cohesion that unifies some distinct individual entities into a single real entity. The glue drives the actions of the group and explains that the members of the firm think 'we' to call themselves and think 'they' to designate a competing firm (Simon, 2002). That's why the etymology of firm is usually treated as singular and is incompatible with plural verbs and pronouns. The firm exhibits a collective social identity ${ }^{7}$ that ensures the durability and the stability of the complex whole. The firm forms a unit that has acquired cohesiveness through time. The actions of the whole are not reducible to the actions of its individualities. It is not because a human constituent leaves the firm that this one is subject to dissolution.

6 Simon (1962:468) defines a complex system as 'one made up of a large number of parts that interact in a nonsimple way'. He adds that 'in such systems, the whole is more than the sum of the parts, not in an ultimate, metaphysical sense, but in the important pragmatic sense that, given the properties of the parts and the laws of their interaction, it is not a trivial matter to infer the properties of the whole' (ibid.).

7 See Davis (2006) for a survey on social identity in economics. 
A particular attention must be devoted to this glue which can be restricted to its institutional and organizational dimensions. The firm is incontestably held together in accordance with a variety of types of glue. By reducing this complex concept of glue to its two dimensions, the aim is to underline that the firm is both an organization and an institution (Hodgson, 2006). On the one hand, the firm is a real institution insofar as it regulates durably individuals' behaviour, ensures behavioural 'conformity' of the individuals composing the unit and prevents and dissipates conflicts. On the other hand, the firm is a real organization insofar as it manages through time a bundle of tangible and intangible, human and non-human productive resources that change and evolve. The glue is the reflection of a synergic interdependence that takes root in a network of specific human investments. But there is not a sharp line between institutional and organizational glues so that both together form a single productive glue that stabilizes intra and interorganizational relationships. The existential glue of the firm generates the integrity and the durability of the whole. Each firm conceals its intrinsic glue.

Knowledge is a strong glue inside the firm. The firm as a productive entity generates specific knowledge (Nonaka et al., 2000). Thus, 'the key assets a corporation uses in production is intellectual capital - that is, the knowledge and experience residing in the minds of its employees, rather than the hands of its shareholders' (Blair and Stout, 1999:261). Without individuals, there is no firm. Individuals are the key constituents of the firm ${ }^{8}$. The firm cannot 'act' without individuals. The identification of individuals to their firm is a necessary condition of cohesiveness and durability. The firm as a 'distributed knowledge system' develops a 'collective mind that is an emergent joint accomplishment rather than an already defined representation of any one individual' (Tsoukas, 1996:15). Dosi (1995) explains thus that the firm must be appreciated under different parts among which the incentive structure, the structure of information flows, the distribution of knowledge and competences but equally the distribution both of formal authority and of power. The exploitation of de jure (formal) and de facto (informal) powers is indeed the best materialization of the existential glue of the firm (see section 4). The firm is a real socio-political entity held in a web of powers and counter-powers.

Finally, contractual theories need to be completed with competence and resource-based views of the firm (see Gibbons, 2005) - which is more and more admitted including among their main supporters (Williamson, 1999; Jacobides and Winter, 2005) - to analyse what a firm is. Resources are tied to the firm with

8 Defining the firm as a real entity implies to 'capture human beings in their full variety and complexity' (Phillips, 1994:1111). Since human beings are shaped by their social relations, it is possible to 'circumscribe' individuals that compose the real entity 'firm'. Individuals that are socially shaped by intra-firm economic relations belong to that firm. 
a precision that the nexus metaphor lacks. Coff (1999:121) explains that 'since strategic resources are node in the nexus that the firm cannot own, the property rights are ambiguous'. But how can economists bypass the mere descriptive use of the firm as 'a collective noun denoting a particular cluster of otherwise ordinary contractual relationships' (Masten, 1988:181)? How can the definition of the firm as a real entity be put in empirical evidence? We think that it is essential to approach these issues by taking into account the emergence of what has been called the network-firm. This complex economic organization is based on some types of control that exist independently both of the subscription of a contract and of vertical ownership integration. Interestingly, the main concern becomes about the real entity that has to be used as the relevant unit of analysis.

\section{A VERTICAL ECONOMIC INTEGRATION WITHOUT EQUITY OWNERSHIP}

In a world of vertically integrated firms with recourse to equity ownership, property rights economists used their theory of the optimal assignment of assets to analyze the boundaries of the firm that were relatively stable and easily defined. But, owing to the movement towards vertical disintegration and the development of complex productive systems - roughly materialized by the modular architecture (see e.g. Langlois, 2002) -, definitions of the firm and analyses of its boundaries based exclusively on asset property rights can no longer be the only relevant ones (Holmström and Roberts, 1998). Vertical interfirm cooperation processes have profoundly affected the relationships between legally independent economic entities and the network-firm is the best evidence of this tendency.

The network-firm refers to a productive entity that unifies a set of legally independent firms vertically integrated and coordinated by a main firm called the 'hub-firm' 'which is the firm that, in fact, sets up the network and takes a proactive attitude in the care of it' (Jarillo, 1988:32). Firms form a network to access complementary and inimitable resources as well as to create an inimitable resource by itself only through its formation. From the resource-based view of the firm, the creation of critical value-generating resources is linked to the firm's network of relationships (Barney, 1991). The ability to incorporate knowledge emanating both from inside and outside the firm's boundaries 'emerges as a distinctive organizational capability' (Lorenzoni and Lipparini, 1999:317). The network-firm can hence be treated as a dynamic network of capabilities. A single firm within the network is required to manage diverse and complementary capabilities. Such an assignment must belong to the hub-firm that controls critical resources as brand name and reputation around which revolve complementary activities that need to be qualitatively and quantitatively coordinated. Critical resources represent the core of the network and the hub-firm carries out the protection of intra-network economic relationships. 
Firms can have recourse to contractual agreements that differ from hierarchy even though assets are strongly specific (Holmström and Roberts, 1998). Despite lock-in effects due to the multilateral dependence, transaction costs are not necessarily high (Dyer 1997). The network-firm is thus built from some specific assets - which can be human, physical, immaterial, temporal, dedicated or sited (Williamson, 1991) - through recurrent relations stamped of uncertainty. In other words, the network-firm seems to be based on the three same Williamsonian conditions that empirically explain de jure vertical integration. These dedicated assets to the hub-firm - which imply specific investments materialized by some high sunk costs - are supposed to be the heart of two linked problems: opportunism and hold-up risks. But interorganizational networks often succeed in maintaining strong market incentives to invest with a low opportunism (see e.g. Zaheer and Venkatraman, 1995). Similarly, property rights views of the firm cannot better explain vertical disintegration since the network-firm functions as a cohesive and sustained whole without recourse to property rights concentration.

Network exchange relationships take the form of non-market relational exchanges (Dore, 1983). The network-firm differs by nature from market. An analysis of the diversity of intra-network incentive and coordination mechanisms is needed to reveal the different elements of the glue that holds the network-firm cohesive. Inter-firm contracts as an institutionalized base are important but trust, which is not contractual in essence, is a necessary condition to network maintenance. Network embeddedness promotes incentives for long-term cooperation and palliates the absence of formalized control systems (Macaulay, 1963). Networks are more based on mutual interests and on reputation as well as less coordinated by a formal authority. Incentive provisions inside the networkfirm are not exclusively contractual but based on some forms of relational and reputational commitments that bind the legal entities together to 'act' as a unified actor. The aim of network-organizations is thus to generate a 'relational quasirent' (Dyer and Singh, 1998:662). Poppo and Zenger (2002:707) conclude that 'formal contracts and relational governance function as complements'.

The network-firm binds a set of independent firms vertically related under the relational power of a hub-firm that takes care of the integrity of the whole. The network-firm is a relational firm (see baker et al., 2002). Orts (1998) argues that relational firms - defined as non traditional firms made between or among simpler firms to act in unison to compete with others in organizational metamarkets - draw attention to the analytical difficulty in defining the boundaries of the firm. Indeed, even if economic relations take place between legally autonomous firms, the firms of the network form together and draw the economic boundaries of a single relational entity that acts, as a dynamic whole of interacting firms, under the legitimate power of the hub-firm. This relational dynamic is confirmed at both intra and interorganizational levels. According to 
Gulati and Gargiulo (1999:1446), the 'relational embeddedness' of the whole network 'highlights the effects of cohesive ties between social actors on subsequent cooperation between those actors'. The relational management of the network-firm strengthens the cohesion of the whole by maintaining the external and internal orders that are respectively related to the preservation of reputation and the durability of collective social identity.

Network governance ties autonomous firms that operate like a single entity in tasks requiring joint action. Firms establish these privileged relationships through strong interactions with each other because there is - across the legal boundaries of the firm - a de facto vertical integration (unspecified contracts, long term view and tasks structured by power). The boundaries of the firm become muddled because they are more and more formed not only by ownership and contract, but also by power.

\section{POWER AS A FACTOR OF COHESION AND DURABILITY}

According to modern property rights theory, formal power matters inside the firm in events not covered by the contract. However, power is not antonymic to efficiency - because power does not occur only owing to some market failures but has some effects on the organization's productive value (Rajan and Zingales, 1998; Palermo, 2000). Since no association of individuals is wholly formal, there is no order and no firm without power. Even though member firms of the network-organization are not integrated into the same lawful structure, the legal contractual autonomy does not imply that the different parties have equal economic power and that they can act freely without restraint (Sacchetti and Sugden, 2003). How does the economic entity 'network-firm' structure the various powers involved and allocate these? Answering to this fundamental question implies proposing a usual definition of power, which is easy to recognize but tricky to define (Pfeffer, 1981). We propose to define power as an individual or collective entity's ability to structure and restrain choices and actions of another entity by some particular mechanisms that are formal as well as informal. Power is the central concept in network analysis and the more typical phenomenon is interdependence (Thorelli, 1986).

According to Galbraith (1979), it is inaccurate to isolate economics from the real world by eluding power and by refusing to consider it as a political science. This argument is valid both within and between firms. Benson (1975:229-230) characterizes the 'interorganizational network' as a 'political economy'. In this sense, he argues that power derives from the central organization's control over strategic contingencies confronted by the peripheral organizations. But, reciprocally, the more contingencies are controlled by a peripheral organization, the greater its power within the network. If power is a constituent property of networks, power has no existence in itself but solely owing to its position in 
economic relationships. Power is not 'an attribute of the actor' (Emerson, 1962:32). Power is, in essence, both a relational and a reputational phenomenon. Even if there are power relationships between legally autonomous firms in the network-firm, this one forms a durable unit. The political order that is entrenched by the distribution of powers in the whole social system is a source of cooperation.

By treating firms as legal entities, mainstream economists cannot explain the mechanisms by which people bind themselves into firms. Power is one of the more important mechanisms. But power does not result exclusively from ownership that, according to the modern theory of property rights, would confer the power to exercise control (Grossman and Hart, 1986). The network-firm cannot be defined according to the ownership of non-human assets. The definition needs to be extended to power that accrues to key social actors having made specific investments around a critical resource of the economic entity and 'who cannot be readily replaced in that function' (Pfeffer, 1981:113). Owing to the creation of dependence positions between the members of a network, power is more widely dispersed among them (Kochan and Rubinstein, 2000). Jacobs (1974) argues that the essentiality of resources is the main determinant of powerdependence relations between organizations. If power is strongly linked to control on key resources, there is not an exclusive power but there are several powers into the network-firm, whereas in the traditional capitalist firm, management power was unilateral. The distribution of power into the networkfirm is realized on the basis of the pattern of interdependencies amongst actors' resources and activities.

The key resources of the network-firm, which are more and more intangible and reputational, are embodied in the human and organizational capital whose rights of control are not directly contractible and difficult to enforce (Asher et al., 2005). Contracts and power act as complements in the coordination of network activities. According to Krackhardt (1990:357), 'the knowledge of the network is in its own right a base of power above and beyond the power accrued through other formal and informal bases'. Intra-network power relationships - which are the result of the entanglement of dynamic network resources - are the materialization of the interorganizational glue that keeps the network-firm together. Emerson (1962) refers to mutual resource dependence as a cohesive effect of the power relation. The cohesive ties between the actors of the network enhance their learning from others' knowledge and permit the emergence of a collective social identity.

The complementarity of critical resources generates a global economic interdependence. This latter can be utilized as the observe of power. The different members of the network - notably the partners that belong to the inner circle dedicate their specialized resources to the hub-firm, participate to the network 
knowledge-creating process and get, like this, a part of the whole power. Network-firm-specific human investments are embodied in a valuable collective learning process that exists only given access to critical resources (Rajan and Zingales, 1998). The consequent problems of coordination may indeed be related to access to and to control of network resources. The power of the hub-firm on its subcontractors is hence legitimated by its key strategic role in the coordination of the whole network. The degree of coordination of the network is strong because of the large number of relational contracts'. This 'coordinator role' confers a durable specific resource and so a power source to the hub-firm. According to Lorenzoni and Lipparini (1999:334), 'the dissemination of knowledge among actors improves the absorptive abilities of the whole network as well as mutual adaptation of network participants'. Access enables the network-firm on the whole to develop its key resources. The control of access to critical resources gives to the hub-firm the legitimate ability to draw the organizational design of the network and so the configuration of powers. The distribution of power due to resource dependence is a necessary condition for the emergence of the networkfirm.

Access is a critical resource in itself that results from strong complementarities and dependences that are said to exist when the unit and the firm can together create more value than they can do in their own separate ways (Rajan and Zingales, 1998). Since access is not strictly contractual ${ }^{10}$, the analysis of the network-firm is accurate to reject the broad use of the term contract in economic theories of the firm and to expand consideration of the true legal basis for the firm. Legally autonomous entities are integrated and coordinated by the controlling and ordering power of the hub-firm that does not originate in contract but in organization itself. The evolution of power exploitation is characterized by the non-exclusivity of de jure sources of power. The growth and the distribution of de facto powers into network-organizations have some large implications on the definition and boundaries of the firm (Rajan and Zingales, 2000). The network-firm differs thus from the firm in a usual sense because its boundaries differ from the perimeter of the legal entity as a nexus of contracts. Such complex organizations have some fundamental implications both in economics and in law, notably in terms of employment contract and legal liability.

\section{From multiplicity to unity: some law and economics of the network-firm}

In this section, the raised question is about the necessity for a firm to be a legal entity to exist. The theorization of the network-firm as a real entity has strong

\footnotetext{
${ }^{9}$ Baker et al. (2002:39) define relational contracts as 'informal agreements sustained by the value of future relationships'.

10 Access results from inter-firm contracts but is per se not contractible.
} 
implications in the field of law and economics of firms. The specialized members of the network-firm constitute the critical human resources that give to the whole growth opportunities. But there are not employment contract and protection between legally independent firms and the hub-firm. Besides, there is not a de jure recognition of the network-firm in terms of legal liability.

\subsection{Beyond the scope of employment protection rights}

Taking into account that a firm is a fairly well-defined contractual structure whose interests are simply an extension of the interests of its owners comes back to think that employees are contracting with the firm but are not themselves a part of it (Blair, 1999). Alchian and Demsetz (1972:111) argue that the firm 'has no power of fiat, no authority, no disciplinary action any different in the slightest degree from ordinary market contracting between any two people'. Authority is just an illusion. Property rights theorists have studied the nature of the firm separately from the structure and terms of relationships with and among its employees. But each employment relationship is intrinsic to a firm and makes it different by nature from the market. Tsuk (2003:1862) reminds that 'there is no one group of people more identified with a corporation and more responsible for its day-to-day conduct than corporate workers'. Employment contract constitutes a strong formal institutional glue that lacks in the network-firm where some critical resources may extend beyond firm's legal boundaries. The economic perimeter of the network-firm is circumscribed by the perimeter of the hub-firm's reputational power. In other words, the exploitation of power draw a perimeter which can be treated as the one of the very network-firm. More generally, the recent trend towards outsourcing of productive modules places the employment relationship beyond the range of employment protection laws (Collins, 1990b).

The relations of power within these inter-firm relations cannot be said to be totally free of legal principles. But the employment relationship assumes a legal particularity that differs from a trading relation between firms even though contractual clauses are susceptible to control the actions of partners. If both transactors have right to sue, the real authority ${ }^{11}$ of the hub-firm has not the same base compared with obligations, sanctions or procedures (Masten, 1988). For example, in automobile industry, the majority of the production workers are employees, not of the hub-firm (auto constructor), but of subcontractors that provide components and modules along the vertical line of production. Yet a focal firm cannot legally aspire to a formal authority on the employees of its subcontractors. For all that, access is a de facto dynamic mechanism that palliates the absence of employment contracts and provides better incentives than ownership; the latter one having adverse effects on the incentive to specialize

${ }^{11}$ See Aghion and Tirole (1997) for an economic distinction between real and formal authority. 
(Rajan and Zingales, 1998). The network-firm has a power distribution with its sources in the interorganizational division of labor. The degree of closeness of human resources towards strategic assets is the main factor in power sharing. Access to critical resources makes that the subunits of a network-firm are mutually related in the interdependent activities of a single social system.

Since any employment contract ties the hub-firm to suppliers' employees, the power of the hub-firm is not de jure but de facto. The analysis of the networkfirm shows a strong separation between the de jure employer (peripheral firm) and the de facto employer (hub-firm) that makes the employment relationship ambiguous. The employment contract is a single employer-employee relationship. But the development of complex economic organizations, where there are multiple employers, has strong implications for both the legal and the socially constituted nature of the employment relationship (Rubery et al., 2002). Ratner (2001) explains that corporations have always wielded significant power, conferred by law, over their employees. It is no longer true with the emergence of such complex vertical organizations. Power does not result exclusively from the law. Collins (1990b:355) argues that 'this raises the question whether the exclusion from employment protection rights is in fact an important reason for vertical disintegration rather than an unfortunate side-effect of other economic forces'. If it seems pertinent to enrich labour law to take into account the relationships of subordination between the hub-firm and its partners and to give rights to employees of subcontractors (Morin, 2005), it seems equally necessary to recognize the network-firm as a single real entity for some particular legal questions. The legal basis is fundamental to theorize the firm. But it does not mean that the network-firm cannot be considered as a real entity because the law does not recognize it.

\subsection{Beyond the scope of politico-legal liability}

Some powerful tansnational firms, from automotive industry to textile and microcomputer industry, have chosen during the 1980's and 1990's to base their activity on outsourcing. Within these constituted productive entities, a hub-firm obtains a huge power to state how relationships with its subcontractors have to be organized. The hub-firm is the 'reputational leader' that coordinates the network, generates the glue, prevents it from dissolution and creates value greater than the sum of its parts by integrating the contributed modules into a single active unit ${ }^{12}$.

12 The term 'network-firm' focuses on the singularity of this organization that implements a single productive process. It is more delicate to qualify a network of firms as a network-firm as soon as some of legally independent firms belong to several entities. In other words, to the level of the firm taken separately, less this one dedicates its activities to a focal firm, more the real 
The properties of the collective entity differ from those of the interacting individual entities and cannot be reduced to them. In the spirit of Cohen (1919:680), the interorganizational glue of the network-firm is this 'something uniting the different individuals (distinct legal entities) so that they act differently than they would if there were not so interdependent'. Van de Ven (1976:28) grasps the network-firm as 'a social action system that exhibits the basic common properties of any form of organized collective behaviour: behaviour is aimed at a goal, interdependence exists between members, and it can act as a unit with an identity separate from its members'. Is the network-firm a firm as such? The answer is 'yes' in an economic sense but 'no' in a legal sense.

The network-firm is not a legal entity with some rights because it is not a moral person. If the network-firm is not a fiction of law, it is not more a 'mindbody unity of real associative personality nor autonomized bundles of resources' (Teubner, 1993:56). The network-firm is a collective unit 'when the relations are so long term and recurrent that it is difficult to speak of the parties as separate entities' and when the 'entangling of obligations and reputation reaches a point that the actions of the parties are interdependent, but there is no common ownership or legal framework' (Powell, 1990:301). The network-firm is a singular real entity regardless of legal structure, as real as any legally recognized firm. There are not de jure sources of liability without equity ownership. Yet the hub-firm's shareholders do not hold shares in the network but only in the hubfirm which does not hold property rights to member firms. The legal definition of the firm matters because the law recognizes firms that constitute the network. But the law needs to be reconsidered as regards with modern organizations that have become a complex and multilevel phenomenon for lawyers and economists. Collins (1990a) then Hansmann and kraakman (1991) have explained that disaggregated organizations raise the problem of the capital boundaries since networks benefit from the power to manipulate capital boundaries in order to reduce or eliminate potential legal liabilities.

The network-firm 'acts' collectively and not through a single action centre. Such a complex organization must be treated as a single real entity in terms of liabilities against outsiders. In the case of outside disturbances, the question is whether the network-firm should react as a whole or whether the parts should react autonomously. Since the network-firm is an integrated functional economic unit, it must also be liability unit in situations where causation damage can be traced back only to the network itself (Teubner, 1993). The network-firm should be considered in some cases as 'a united group for the purpose of the ascription of legal personality’ (Collins, 1990a:744). In this view, Ballantine (1943:426) suggests to disregard the corporate entity as a regulatory process in order to

entity constituting the relevant unit of analysis tends to the legal entity 'firm' that the law recognizes. 
prevent from the use or abuse of a separate corporate entity to carry out a scheme for evasions of statutes and legal duties.

It is accurate to treat the network-firm as a single entity and not as a set of entities because with tort victims it is the reputation of the network-firm which is weakened. It is not important for consumers to know the identity of the firms that compose the network. When a product does not work right, consumer does not search who is in tort or who has produced the faulty component or system. The whole is affected but the network itself is not sued. It is the hub-firm that is sued and not other network members, although the hub-firm can sue its 'flawed' partner. But the reputation and so the cohesion of the collective entity are sensibly damaged. Reputation effects are crucial in contexts of strategically interdependent actors (Raub and Weesie, 1990). Vertically, the hub-firm's reputation could affect the legitimacy of its partners and vice versa because the legitimacy of the collective entity is not independent of the legitimacy of cognitively related entities (Kostova and Zaheer, 1999). This damage in reputation can be deemed as a collective sanction that foreshadows de facto responsibilities. With these new forms of action attribution, new risks emerge and, according to Teubner (1993), the specific character of the network suggests a joint politico-legal liability. But this liability should be reindividualized in function of the degree of decentralization of the network in aid of 'a threefold responsibility of collective, centre, and individual unit' (ibid.:60). Finally, Teubner shows that 'piercing the contractual veil' like the network-firm makes should result in the institutionalization of a selectively combined liability of the network.

If the case of multinational business groups is attractive for understanding why the firm is a real entity (see Douglas and Shanks, 1926), the case of the network-firm is more suitable because it allows to exclude the role of equity ownership in the economic integration of the whole. An important issue should lastly be raised: does equity ownership generate more cohesiveness than a less formal integration?

\section{CONCLUSION}

Law provides for a set of legal entities that are simply 'standard-form contracts among the parties who participate in an enterprise' (Hansmann and Kraakman, 2000:387). Economic considerations dominate corporate law and are responsible for introducing the contractual paradigm and the property rights paradigm for the firm (Iacobucci and Triantis, 2007). Yet the firm is more than a nexus of contracts or group of assets. Because they are weighty reductionist, contractual economic theories take 'aggregate rather than an entity, approach-separate relationships comprised the corporation's ontological center than the force of the collective effort' (Bratton, 1989:1489). By contrast with 
such reductionist positions, each firm - including the network-firm - is a real emergent entity and not an aggregation of individuals or of distinct legal entities. Market, hierarchy, network and other organizational forms each represent separate social entities which differ from each other not in degree but in their ontological nature.

Without recourse to equity ownership, the network-firm succeeds in making some legally independent firms a single active unit. Beyond such important legal bases as employment contract and legal liability, the network-firm exists intrinsically and is perpetuated by some integrating forces (glues) strengthened by the exploitation of powers. These interorganizational powers explain the networkfirm's ability to cope with changing environment. If it seems clear that new protective rules provided by law would be relevant in some cases, the question of the legal recognition of the network-firm as a single emergent entity is an endless debate. Does the network-firm benefit from and emerge owing to a legal incompleteness (see Baudry and Gindis, 2005)? What is sure is that the legal recognition is neither a necessary nor a sufficient condition for the emergence of the network-firm and to theorize it as a single real entity.

\section{REFERENCES}

Aghion, M. and J. Tirole. 1997. 'Formal and Real Authority in Organizations', 105(1) Journal of Political Economy 1-29.

Alchian, A.A. and H. Demsetz. 1972. 'Production, Information Costs, and Economic Organization', 62(5) American Economic Review 777-795.

Asher, C.C., Mahoney, J.M. and J.Y. Mahoney. 2005. 'Towards a Property Rights Foundation for a Stakeholder Theory of the Firm', 9(1) Journal of Management and Governance 5-32.

Baker, G.P., Gibbons, R. and K.J. Murphy. 2002. 'Relational Contracts and the Theory of the Firm', 107(1) Quarterly Journal of Economics 39-84.

Ballantine, H.W. 1926. 'Corporations: Disregarding the Corporate Entity as a Regulatory Process', 31(4) California Law Review 426-429.

Barney, J.B. 1991. 'Firm Resources and Sustained Competitive Advantage', 17(1) Journal of Management 99-120.

Baudry, B and D. Gindis. 2005. 'The V-Network Form: Economic Organization and the Theory of the Firm', SSRN Working Paper, http://ssrn.com/abstract=795244.

Benson, J.K. 1975. 'The Interorganizational Network as a Political Economy', 20(2) Administrative Science Quarterly 229-249.

Blair, M.M. 1999. 'Firm-specific Human Capital and Theories of the Firm', in : BLAIR, M. and M. RoE (eds.), Employee and Corporate, Washington A.C.: Brookings Institute.

Blair, M.M. and L.A. Stout. 1999. 'A Team Production Theory of the Corporate Law', 85(2) Virginia Law Review 247-328.

Blumberg, P.L. 1990. 'The Corporate Personality in American Law: A Summary Review', 38 American Journal of Comparative Law 49-69. 
Bratton, W.W. 1989. 'The New Economic Theory of the Firm: Critical Perspectives from History', 41(6) Stanford Law Review 1471-1527.

Brown, W.J. 1905. 'The Personality of the Corporation and the State', 21(4) Law Quarterly Review 365-379.

Cheung, S. 1983. 'The Contractual Nature of the Firm', 26(1) Journal of Law and Economics 121.

Coase, R.H. 1937. 'The Nature of the Firm', 4(16) Economica 368-405.

Coff, R.W. 1999. 'When Competitive Advantage Doesn't Lead to Performance: The ResourceBased View and Stakeholder Bargaining Power', 10(2) Organization Science 119-133.

Cohen, M.R. 1919. 'Communal Ghosts and Other Perils in Social Philosophy', 16(25) Journal of Philosophy, Psychology and Scientific Methods 673-690.

Cohen, F.S. 1935. 'Transcendental Nonsense and the Functional Approach', 35(6) Columbia Law Review 809-849.

Collins, H. 1990a. 'Ascription of Legal Personality to Groups in Complex Patterns of Economic Integration’, 53(6) Modern Law Review 731-744.

Collins, H. 1990b. 'Independent Contractors and the Challenge of Vertical Disintegration to Employment Protection Laws', 10(3) Oxford Journal of Legal Studies 353-380.

Collins, H. 1993. 'Organisational Regulation and the Limits of Contract', in J. McCahery, S. Picciotto and C. Scott (eds.), Corporate Control and Accountability: Changing Structures and the Dynamics of Regulation. Oxford: Clarendon Press.

Davis, J.B. 2006. 'Social Identity Strategies in Recent Economics', 13(3) Journal of Economic Methodology 371-390.

Demsetz, H. 1988. 'The Theory of the Firm Revisited', 4(1) Journal of Law, Economics and Organization 141-161.

Dewey, J. 1926. 'The Historic Background of Corporate Legal Personality', 35(6) Yale Law Journal 655-673.

Dicey, A.V. 1904. 'The Combination Laws as Illustrating the Relation between Law and Opinion in England during the Nineteenth Century', 17(8) Harvard Law Review 511-532.

Dore, R. 1983. 'Goodwill and the Spirit of Market Capitalism', 34(4) British Journal of Sociology $459-482$.

Douglas, W.O. and C.M. Shanks. 1926. 'Insulation from Liability through Subsidiary Corporations', 39(2) Yale Law Journal 193-218.

Dosi, G. 1995. 'Hierarchies, Market and Power: Some Foundational Issues on the Nature of Contemporary Economic Organization', 4(1) Industrial and Corporate Change 1-17.

Dyer, J.H. 1997. 'Effective Inter-firm Collaboration: How Firms Minimize Transaction Costs and Maximise Transaction Value’, 18(7) Strategic Management Journal 535-557.

Dyer, J.H. and H. Singh. 1998. 'The Relational View: Cooperative Strategy and Sources of Interorganizational Competitive Advantage’, 23(4) Academy of Management Review 660-679.

Emerson, R.M. 1962. 'Power-Dependence Relations', 23(4) American Sociological Review 3141.

Foley, H.E. 1929. 'Incorporation, Multiple Incorporation and the Conflict of Laws', 42(4) Harvard Law Review 516-549.

Galbraith, J.K. 1979, Annals of an Abiding Liberal. Boston: Houghton Mifflin. 
Gibbons, R. 2005. 'Four formal(izable) theories of the firm', 58(2) Journal of Economic Behavior \& Organization 200-245.

Gindis, D. (2007), 'Some Building Blocks for a Theory of the Firm as a Real Entity', in Y. Biondi, A. Canziani and T. Kirat (eds.), The Firm as an Entity: Implications for Economics, Accounting and Law. New-York: Routledge.

Grossman, S.J. and O.D. Hart. 1986. 'The Costs and Benefits of Ownership: A Theory of Vertical and Lateral Integration', 94(2) Journal of Political Economy 691-719.

Gulati, R. and M. Gargiulo. 1999. 'Where Do Interorganizational Networks Come From?', 104(5) American Journal of Sociology 1439-1493.

Hansmann, H. and R. Kraakman. 1991. 'Toward Unlimited Shareholder Liability for Corporate Torts', 100(7) Yale Law Journal 1879-1934

Hansmann, H. and R. Kraakman. 2000. 'The Essential Role of Organizational Law', 110(3) Yale Law Journal 387-440.

Hart, O.D. 1995. Firms, Contracts, and Financial Structure. Oxford: Oxford University Press.

Hart, O.D. and J.M. Moore. 1990. 'Property Right and the Nature of the Firm', 98(6) Journal of political Economy 1119-1156.

Hodgson, G. M. 2002. 'The Legal Nature of the Firm and the Myth of the Firm-Market Hybrid', 9(1) International Journal of the Economics of Business 36-60.

Hodgson, G.M. 2006. 'What are Institutions?', 40(1) Journal of Economic Issues, 1-25.

Holland, J.H. (1998), Emergence: From Chaos to Order. Oxford : Oxford University Press.

Holmström, B. and J. Roberts. 1998. 'The Boundaries of the Firm Revisited', 12(4) Journal of Economic Perspectives 73-94.

Humphreys, P. 1997. 'Emergence, Not Supervenience', 64(4) Philosophy of Science 337-345.

Iacobucci E.M. and G.G. Triantis. 2007. 'Economic and Legal Boundaries of Firms', 93(3) Virginia Law Review 515-569.

Ireland, P. 1999. 'Company Law and the Myth of Shareholder Ownership', 62(1) Modern Law Review, 32-57.

Jacobides, M. and S. Winter. 2005. 'Capabilities, transaction costs, and evolution: understanding the institutional structure of production', 26(5) Strategic Management Journal 395-413.

Jacobs, D. 1974. 'Dependence and Vulnerability: An Exchange Approach to the Control of Organizations', 19(1) Administrative Science Quarterly 45-69.

Jarillo, J.C. 1988. 'On Strategic Networks', 9(1) Strategic Management Journal 31-41.

Jensen, M. and W. Meckling. 1976. 'Theory of the Firm: Managerial Behaviour, Agency Costs, and Ownership Structure', 3(2) Journal of Financial Economics 305-360.

Kay, J. and A. Silberston. 1995. 'Corporate Governance', 153(1) National Institute Economic Review 84-107.

Kochan, T.A. and S.A. Rubinstein. 2000. 'Toward a Stakeholder Theory of the Firm: The Saturn Partnership', 11(4) Organization Science 367-386.

Kostova, T and S. Zaheer. 1999. 'Organizational Legitimacy under Conditions of Complexity: The Case of the Multinational Enterprise', 24(1) Academy of Management Review 64-81.

Krackhardt, D. 1990. 'Assessing the Political Landscape: Structure, Cognition, and Power in Organizations’, 35(2) Administrative Science Quarterly 342-369. 
Langlois, R.N. 2002. 'Modularity in Technology and Organization', 49(1) Journal of Economic Behaviour and Organization 19-37.

Laski, H.J. 1916. 'The Personality of Associations', 29(4) Harvard Law Review 404-426.

Lorenzoni, G. and A. Lipparini. 1999. 'The Leveraging of Interfirm Relationships as a Distinctive Organizational Capability: A Longitudinal Study', 20(4) Strategic Management Journal 317338.

Macaulay, S. 1963. 'Non-Contractual Relations in Business: A Preliminary Study', 28(1) American Sociological Review 55-67.

Machen, A. W. 1911. 'Corporate Personality', 24(4) Harvard Law Review 253-267 and 347- 365.

Maitland, F.W. 1905. 'Moral Personality and Legal Personality', 6(2) Journal of the Society of Comparative Legislation 192-200.

Mark, G. A. 1987. 'The personification of the Business Corporation in American Law, 54(4) University of Chicago Law Review 1441-1483.

Masten, S.E. 1988. 'A Legal Basis for the Firm', 4(1) Journal of Law, Economics \& Organization 181-198.

McKelvey, B. 1997. 'Quasi-Natural Organization Science', 8(4) Organization Science 352-380.

Moore, J. 1992. 'The Firm as a Collection of Assets', 36(2-3) European Economic Review 493507.

Morin, M.-L. 2005. 'Labour Law and New Forms of Corporate Organization', 144(1) International Labour Review 5-30.

Nonaka, I., Toyama, R. and A. Nagata. 2000. 'A Firm as a Knowledge-Creating Entity: A new Perspective on the Theory of the Firm', 9(1) Industrial and Corporate Change 1-20.

Orts, E.W. 1998. 'Shirking and Sharking: A Legal Theory of the Firm', 16(2) Yale Law and Policy Review 265- 329.

Palermo, G. 2000. 'Economic Power and the Firm in New Institutional Economics: Two Conflicting Problems', 34(3) Journal of Economic Issues 573-601.

Pfeffer, J. 1981. Power in Organizations. Marshfield, MA: Pitman Publishing.

Phillips, M.J. 1994. 'Reappraising the Real Entity Theory of the Corporation', 21(4) Florida State University Law Review 1061-1122.

Poppo, L. and T. Zenger. 2002. 'Do Formal Contracts and Relational Governance Function as Substitutes or Complements', 23(8) Strategic Management Journal 707-725.

Powell, W.W. 1990. 'Neither market nor hierarchy: network forms of organization'. 12 Research in Organizational Behavior 295-336.

Rajan, R.G. and L. Zingales. 1998. 'Power in a Theory of the Firm', 113(2) Quarterly Journal of Economics 387-432.

Rajan, R.G. and L. Zingales. 2000. 'The Governance of the New Enterprise' in X. Vives (ed.), Corporate Governance: Theoretical and Empirical Perspectives. Cambridge: Cambridge University Press.

Ratner, S.R. 2001. 'Corporations and Human Rights: A Theory of Legal Responsibility', 111(3) Yale Law Journal 443-545.

Raub, W. and J. Weesie. 1990. 'Reputations and Efficiency in Social Interactions: An Example of Network Effects', 96(3) American Journal of Sociology 626-654. 
Raymond, R.L. 1906. 'The Genesis of the Corporation', 19(5) Harvard Law Review 350-365.

Rubery, J., Earnshaw, J., Marchington, M., Cooke, F.L., Vincent, S. 2002. 'Changing Organizational Forms and the Employment Relationship', 39(5) Journal of Management Studies 645-672.

Sacchetti, S. and R. Sugden. 2003. 'The Governance of Networks and Economic Power: The Nature and Impact of Subcontracting Relationships', 17(5) Journal of Economic Surveys 669690.

Simon, H.A. 1962. 'The Architecture of Complexity', 106(6) Proceedings of the American Philosophical Society 467-482.

Simon, H.A. 2002. 'We and They: The Human Urge to Identify with Groups', 11(3) Industrial and Corporate Change 607-610.

Teubner, G. 1988. 'Enterprise Corporatism: New Industrial Policy and the Essence of the Legal Person', 36(1) American Journal of Comparative Law 130-155.

Teubner, G. 1993. 'The Many-Headed Hydra: Networks as Higher-Order Collective Actors', in McCahery S., Picciotto S. and C. Scott (eds.), Corporate Control and Accounatbility: Changing Structures and the Dynamics of Regulation. Oxford: Clarendon Press.

Teubner, G. 2002. 'Hybrid Laws: Constitutionalizing Private Governance Networks', in R. Kagan, M. Krygier and K. Winston (eds.), Legality and Community. Berkeley: Berkeley Public Policy Press.

Thorelli, H.B. 1986. 'Networks: Between Markets and Hierarchies', 7(1) Strategic Management Journal 37-51.

Tsoukas, H. 1996. 'The Firm as a Distributed Knowledge System: A Constructionist Approach', 17 (Special Issue: Knowledge and the Firm) Strategic Management Journal 11-25.

Tsuk, D. 2003. 'Corporations without Labor: The Politics of Progressive Corporate Law', 151(6) University of Pennsylvania Law Review 1861-1912.

Van de Ven, A.H. 1976. 'On the Nature, Formation, and Maintenance of Relations among organizations', 1(4) Academy of Management Review 24-36.

Williamson, O.E. 1991. 'Comparative Economic Organization: The Analysis of Discrete Alternative', 36(2) Administrative Science Quarterly 269-296.

Williamson, O.E. 1999. 'Strategy Research: Governance and Competence Perspectives', 20(12) Strategic Management Journal 1087-1108.

Williamson, O.E. 2002. 'The Lens of Contract: Private Ordering', 92(2) American Economic Review 438- 443.

Williston, S. 1888. 'History of the Law of Business Corporations before 1800. I', 2(3) Harvard Law Review 105-124.

Zaheer, A. and N. Venkatraman. 1995. 'Relational Governance as an Interorganizational Strategy: An empirical Test of the Role of Trust in Economic Exchange', 16(5) Strategic Management Journal 373-392. 